\title{
Article \\ Endophytic Community Composition and Genetic-Enzymatic Features of Cultivable Bacteria in Vaccinium myrtillus L. in Forests of the Baltic-Nordic Region
}

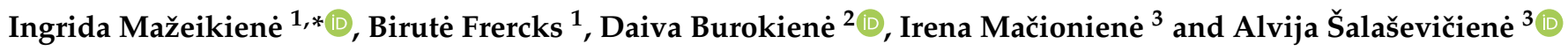 \\ 1 Lithuanian Research Centre for Agriculture and Forestry, Institute of Horticulture, Babtai, \\ LT-54333 Kaunas, Lithuania; birute.frercks@lammc.lt \\ 2 Nature Research Centre, Institute of Botany, Akademijos Street 2, 08412 Vilnius, Lithuania; \\ daiva.burokiene@gamtc.lt \\ 3 Food Institute, Kaunas University of Technology, Radvilenu Avenue 19, 50292 Kaunas, Lithuania; \\ irena.macioniene@ktu.lt (I.M.); alvija.salaseviciene@ktu.lt (A.Š.) \\ * Correspondence: ingrida.mazeikiene@lammc.lt; Tel.: +370-37-555253
}

Citation: Mažeikienè, I.; Frercks, B.; Burokienè, D.; Mačionienè, I.; Šalaševičienè, A. Endophytic Community Composition and Genetic-Enzymatic Features of Cultivable Bacteria in Vaccinium myrtillus L. in Forests of the Baltic-Nordic Region. Forests 2021, 12, 1647. https://doi.org/10.3390/ f12121647

Academic Editor: Benedetto T. Linaldeddu

Received: 27 October 2021

Accepted: 24 November 2021

Published: 27 November 2021

Publisher's Note: MDPI stays neutral with regard to jurisdictional claims in published maps and institutional affiliations.

Copyright: (c) 2021 by the authors. Licensee MDPI, Basel, Switzerland. This article is an open access article distributed under the terms and conditions of the Creative Commons Attribution (CC BY) license (https:// creativecommons.org/licenses/by/ $4.0 /)$.

\begin{abstract}
Regardless of their growth locations and species diversity, plants have endophytic bacterial communities. Bilberry (Vaccinium myrtillus L.) is valuable for human health because of its antioxidant properties, and the plant has adapted to stressful growing conditions in forests. Here, we aimed to describe the composition of the community of endophytic microorganisms in bilberry leaves and to determine whether the diversity of endophytic bacteria varies depending on the geographical location of the plants. In this study, we evaluated the significance of endophytes in the host plant and the potential use of such bacteria. Twenty-five culturable bacterial isolates were identified in $V$. myrtillus leaves based on $16 \mathrm{~S}$ rRNA gene sequencing and phylogenetic analysis. For the first time, we report upon the diversity of endophytic communities coexisting in bilberry leaves in different geographical locations of the Nordic-Baltic region. Under harsh conditions, the bilberry plants had a greater diversity of bacteria. The bacterial families Bacillaceae, Paenibacillaceae and Micrococcaceae were the most common endophytes in leaves of bilberry. Strains of Staphylococcaceae, Lactobacillaceae, Pseudomonaceae, Corynebacteriaceae and Planococcaceae were identified in samples from Finland and Norway. Plant growth-promoting genes ( $a c d S$ and $A c P h o$ ) and/or enzymatic activity were identified in many isolates.
\end{abstract}

Keywords: Vaccinium myrtillus L.; endophytes; acdS gene; AcPho gene; enzymatic activity

\section{Introduction}

Microorganisms are one of the most important organisms that can develop beneficial associations with plants [1]. Endophytes are a group of microorganisms that reside in healthy plants and do not cause a pathogenic effect, which is why such organisms are of increasing interest to scientists in different research areas [2]. Endophytic bacteria, as a main component of the plant microbiota, thrive in plants and may improve plant growth under normal conditions and (or) provide a protective response to biotic or abiotic stress [3]. Numerous studies have confirmed that endophytes play an important role in the synthesis of secondary metabolites and act as plant growth regulators because of their resistance to plant diseases or environmental stressors [2,4-7]. A wide range of endophytic bacterial communities have been identified in wild or cultural plant species [3,8-11]. The primary pathway for bacteria to enter the plant is through the roots, but the final site of accumulation for these specialized endophytic bacteria is leaves tissue [12]. Nevertheless, only a few bacteria can colonize aerial vegetative parts of host plants because of the physiological properties required to occupy these plants tissues [3]. The endophytic diversity in a plant and in a particular community may depend on several factors, such as the genetics, 
morphology, and physiology of a certain host plant. The growth site and environmental conditions of the host plant may also affect the diversity of endophytic bacteria [13].

Bilberry (Vaccinium myrtillus L.) is a useful wild berry in Europe. Bilberry is a natural resource, and various parts of the plant contain many benefits for human health and have been used in traditional European medicine for more than 1000 years. Nutritional composition and antioxidant activity due to the abundance of phenolic compounds in leaves extracts are beneficial to human health [14,15]. The growing area of $V$. myrtillus is native to Europe, but this species is also found in temperate and sub-Arctic regions around the world. Bilberries are widely abundant and easily found in the forests of Lithuania, Latvia, Finland, and Norway. Well-drained, moist, acidic soils are best for this species, but it can also grow in very acidic soils ( $\mathrm{pH} 4.5-6$ ). Thus, the adaptation and secondary metabolism of $V$. myrtillus plants can be synergistically affected by microbial endophytes, the benefits and potential of which are, in many cases, unknown in wild forest plants. In addition, some endophytes have shown a good ability to colonize host plant tissues; therefore, bacteria have a beneficial effect on plant growth by providing plants with the necessary nutrients or bioactive compounds [16-19]. Many beneficial microorganisms from different plant species and environments have recently been identified that can act as sources of new bioactive compounds and can therefore be used in the medical, agricultural or food industries. Numerous microbiological and ecological studies have shown that plant endophytes and their products may be promising candidates as a biological control measure.

The aim of this study was to describe the composition of the endophytic bacterial community in V. myrtillus L. leaves and evaluate the influence of geographical plant origin on the diversity of endophytic bacteria.

\section{Materials and Methods}

\subsection{Collection of Plant Material}

Bilberry leaves (V. myrtillus L.) were collected in July 2020. Plant material samples were collected from three different locations in each of the Baltic-Nordic countries (Lithuania, Latvia, Finland, and Norway) (Figure 1), taken to the laboratory in sealed plastic bags and stored at $-18{ }^{\circ} \mathrm{C}$ until further analysis.

\subsection{Isolation of Endophytic Bacteria}

The bilberry leaf surfaces were disinfected according to the following protocol applied in our laboratory: soaking in 70\% ethanol for $5 \mathrm{~min}, 4 \%$ sodium hypochlorite for $5 \mathrm{~min}$, $70 \%$ ethanol for $1 \mathrm{~min}$, and finally rinsing five times with sterile, distilled water. Test samples were homogenized in $10 \mathrm{~mL}$ of sterile water using a sterile mortar and pestle. Leaf tissue extract was spread on LB (Luria Bertani agar) (Liofilchem diagnostici, Roseto degli Abruzzi, Italy) plates and incubated for up to $5-7$ days at $30^{\circ} \mathrm{C}$, after which each Petri dish was evaluated. For sterility control, healthy sterile leaves or berries were placed on LB agar. To confirm the disinfection protocol, aliquots of sterile water used in the final rinse were plated on LB agar.

\subsection{Classification of Isolated Endophytic Bacteria}

Bacterial classification was performed using sequence analysis of the 16S rRNA gene. Total DNA of each strain was extracted using the GeneJET Genomic DNA Purification Kit (Thermo Scientific, Vilnius, Lithuania) according to the manufacturer's instructions. The primers E8 F/U1510R [20] were used to amplify the 16S rRNA gene. The PGR reaction mix was carried out in a volume of $20 \mu \mathrm{L}$ and was composed of $10 \times$ TaqDNA polymerase buffer $2.5 \mu \mathrm{L}, 2.5 \mathrm{mM} \mathrm{MgCl} 22 \mu \mathrm{L}, 0.2 \mathrm{mM}$ dNTP mix $2 \mu \mathrm{L}, 0.1 \mu \mathrm{M}$ forward and reverse primer $0.2 \mu \mathrm{L}, 0.1$ unit Taq DNA polymerase (Thermo Scientific, Vilnius, Lithuania) and $100 \mathrm{ng}$ of DNA. The amplification reaction was performed in a Mastercycler gradient $\mathrm{S}$ thermal cycler (Eppendorf Ltd., Stevenage, UK) under the following conditions: initial denaturation at $95{ }^{\circ} \mathrm{C}$ for $3 \mathrm{~min}, 35$ cycles of amplification at $94{ }^{\circ} \mathrm{C}$ for $40 \mathrm{~s}, 55^{\circ} \mathrm{C}$ for $90 \mathrm{~s}$ and $72{ }^{\circ} \mathrm{C}$ for $2 \mathrm{~min}$, followed by a final extension step at $72{ }^{\circ} \mathrm{C}$ 
for $15 \mathrm{~min}$. After visualization on 1.2\% agarose gel, PCR products were cut and purified using the GeneJET Gel Extraction Kit (Thermo Scientific, Vilnius, Lithuania) and then sequenced using the Sanger method using the BigDye Terminator v3.1 Cycle Sequencing Kit (Applied Biosystems, Waltham, MA, USA) in the laboratory. Twenty-five sequences were subjected to analysis using the Basic Local Alignment Search Tool (BLAST) program in the National Center for Biotechnology Information (NCBI) database to determine sequence similarity. Biodiversity visualization of culturable endophytic bacteria was performed using Krona2 [21]. The bacterial collection is stored in the Microorganisms Collection of the Food Institute of KTU and in the Cryopreservation laboratory of LAMMC.

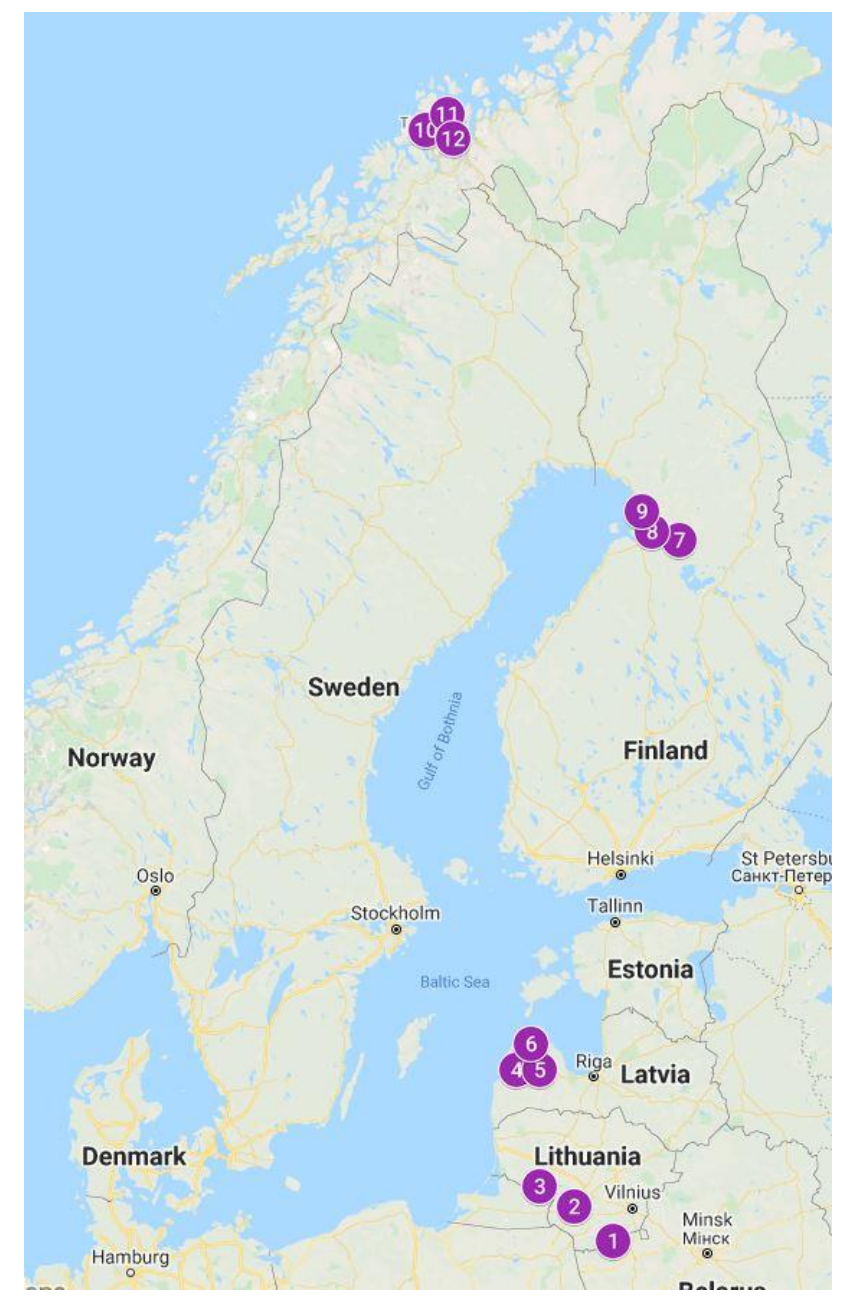

Figure 1. Geographic locations of the samples collection places. Coordinates of the bilberry leaves sampling places in Lithuania: 1-54.1228583/24.7169587; 2-54.7215902/23.5088667; 3-55.0746818/ 22.4706382; in Latvia: 4-57.142528/21.865862, 5-57.150996/21.851492, 6-57.146518/21.872110; in Finland: 7-64.861507/26.704433, 8-64.98617/25.903658, 9-65.229213/25.559873; in Norway: 1069.6944201/18.9911423, 11-69.7512821/19.0257227, 12-69.6708430/18.618162.

\subsection{Determination of the Enzymatic Activity of the Bacterial Endophytes}

Determination of amylases and proteases: The presence of amylase and proteolytic enzymatic activity was determined using LB agar (Liofilchem diagnostici, Roseto degli Abruzzi, Italy) supplemented with $1 \%(w / v)$ soluble starch and $1 \%(w / v)$ gelatin. Freshly prepared bacterial endophytes were inoculated on agar as spot dots and incubated at $30^{\circ} \mathrm{C}$ for $24-48 \mathrm{~h}$. After incubation, the plates were flooded with $1 \%$ iodine solution, and the appearance of a transparent zone around the bacterial colonies confirmed the presence of amylases. Gelatin hydrolysis was observed after flooding the plates with acidic mercuric chloride as an indicator. A clear or lightly colored halo around the colonies indicated a 
positive reaction [22]. The enzymatic bacterial activity was assessed three times, and scales according to the halo zones on agar in millimeters were estimated.

Determination of catalase activity. For catalase activity, a drop of hydrogen peroxide $(3 \%)$ was added to a colony of endophytic bacteria, and oxygen was observed by bubble formation [22].

\subsection{Identification of Genes Involved in Plant Growth Promotion}

The genes responsible for the synthesis of 1-aminocyclopropane-1-carboxylate (ACC) deaminase $(a c d S)$ and acid phosphatase $(A c P h o)$ enzymes were identified using primers specific for these genes [23]. The PGR reaction mix was carried out in a volume of $20 \mu \mathrm{L}$ and was composed of $10 \times$ TaqDNA polymerase buffer $2.5 \mu \mathrm{L}, 2.5 \mathrm{mM} \mathrm{MgCl}_{2} 2 \mu \mathrm{L}, 0.2 \mathrm{mM}$ dNTP mix $2 \mu \mathrm{L}, 0.1 \mu \mathrm{M}$ forward and reverse primer $0.2 \mu \mathrm{L}, 0.1$ unit Taq DNA polymerase (Thermo Scientific, Vilnius, Lithuania), and $100 \mathrm{ng}$ of DNA. The amplification reaction was performed in a Master-cycler gradient $S$ thermal cycler (Eppendorf Ltd., Stevenage, UK) under the following conditions: initial denaturation at $95^{\circ} \mathrm{C}$ for $3 \mathrm{~min}, 35$ cycles of amplification at $94^{\circ} \mathrm{C}$ for $30 \mathrm{~s}, 52^{\circ} \mathrm{C}(\operatorname{acdS})$, and $55^{\circ} \mathrm{C}(\mathrm{AcPho})$ for $45 \mathrm{~s}$, and $72{ }^{\circ} \mathrm{C}$ for $1 \mathrm{~min}$, and the reaction was completed at $72{ }^{\circ} \mathrm{C}$ for $10 \mathrm{~min}$. PCR products were visualized on $1.2 \%$ agarose gel by staining with ethidium bromide. Amplification product sizes were estimated using the molecular DNA marker GeneRulerTM 1kb DNA Ladder Mix (Thermo Scientific, Vilnius, Lithuania). The agarose gels were documented and assessed using a Herolab UV chamber and the E.A.S.Y Win 32 documentation program.

\section{Results}

\subsection{Biodiversity of Endophytic Bacteria in Bilberry Leaves}

A total of 25 genetically distinct endophytic bacteria were isolated from the leaves of $V$. myrtillus according to the sequence data of the 16S rRNA gene (Table 1). BLAST and phylogenetic analysis of $16 \mathrm{~S}$ rRNA gene sequences revealed that the endophytic bacterial isolates were $99.58-100 \%$ similar to the sequences available in the NCBI GenBank. The 16S rDNA nucleotide sequences were submitted to GenBank and assigned accession numbers MZ469297 to MZ469321. The genetic identity among the sequences was found to be $100 \%$ in 18 bacteria strains. The $16 S$ rRNA gene sequences demonstrated that strains Bil-LT1_1, BilLT1_2, Bil-LT4_7, Bil-LV3_1, and Bil-FIN2_3 were identical to several Bacillus spp. species from NCBI; however, due to genetic similarity within the Bacillus spp. species, precise identification of the isolates should be performed for further studies. The same situation was observed for strains Bil-LT4_8 and Bil-NOR3_14, which were related to Micrococcus sp., and strains Bil-Bil-2_5, Bil-Bil-2_6, and Bil-NOR3_11, which were related to Staphylococcus sp. One strain, Bil-FIN2_7, was related to Lysinibacillus spp. Three strains (Bil-LV3_4, LV3_6, and NOR3_18) with minor nucleotide polymorphisms were closely related to Paenibacillus spp. Strains of endophytic bacteria, such as Rothia amarae (Bil-LT4_1), Paenibacillus tundrae (Bil-LV3_3), Kocuria kristinae (Bil-FIN2_9, Bil-FIN2_13), Weissella hellenica (Bil-FIN2_10), Micrococcus terreus (Bil-FIN2_12), Corynebacterium freneyi (Bil-NOR3_13), Pseudomonas monteilii (Bil-NOR3_15), Sporosarcina aquimarina (Bil-NOR3_16), and Paenibacillus xylanexedens (Bil-NOR3_17), were identified in bilberry leaves.

The biodiversity of endophytic bacteria in bilberry leaves from the countries of the Baltic-Nordic region (Lithuania, Latvia, Finland, and Norway) was investigated and is shown in Figure 2. Endophytic bacteria isolated from bilberry leaves belonged to the phyla Firmicutes 64\%, Actinobacteria 32\%, and Proteobacteria 4\%. Bacteria of the families Bacillaceae, Paenibacillaceae, and Micrococcaceae were the most frequently isolated and identified in blueberry leaves. Staphylococcaceae, Lactobacillaceae, Pseudomonaceae, Corynebacteriaceae, and Planococcaceae strains were identified in one or more cases. 
Table 1. Comparative matches for the closest phylogenetic genotypes (according NCBI records) obtained for the culturable bacteria isolates based on profile of $16 \mathrm{~S}$ rRNA gene.

\begin{tabular}{|c|c|c|c|}
\hline Isolate & Accession Number in NCBI & Identity Accessions, According NCBI & Sequence Length, bp (Identity, \%) \\
\hline Bil-LT1_1 & MZ469297 & $\begin{array}{c}\text { Bacillus halotolerans MK517597.1 } \\
\text { B. mojavensis MF040286.1 } \\
\text { B. velezensis MT634548.1 } \\
\text { B. axarquiensis GU568194.1 } \\
\text { B. subtilis AB526464.1 }\end{array}$ & $1437(100)$ \\
\hline Bil-LT1_2 & MZ469298 & $\begin{array}{l}\text { Bacillus simplex LK391525.1 } \\
\text { Peribacillus butanolivorans CP050509.1 }\end{array}$ & $1431(100)$ \\
\hline Bil-LT4_1 & MZ469299 & Rothia amarae MG905369.1 & $1400(99.79)$ \\
\hline Bil-LT4_3 & MZ469300 & Bacterium strain MTL8-4 MH151301.1 & $1439(99.58)$ \\
\hline Bil-LT4_7 & MZ469301 & $\begin{array}{c}\text { Bacillus zhangzhouensis MN826587.1 } \\
\text { B. pumilus CP054310.1 } \\
\text { B. safensis KJ542766.1 } \\
\text { B. stratosphericus KY203662.1 }\end{array}$ & $1420(100)$ \\
\hline Bil-LT4_8 & MZ469302 & $\begin{array}{l}\text { Micrococcus sp. MG132043.1 } \\
\quad \text { M. luteus AJ409096.1 }\end{array}$ & $1398(100)$ \\
\hline Bil-LV3_1 & MZ469303 & $\begin{array}{l}\text { Bacillus sp. strain MK736127.1 } \\
\text { B. aryabhattai MN515130.1 } \\
\text { B. megaterium MF988696.1 }\end{array}$ & $1427(100)$ \\
\hline Bil-LV3_3 & MZ469304 & Paenibacillus tundrae HF545335.1 & $1431(100)$ \\
\hline Bil-LV3_4 & MZ469305 & Paenibacillus sp. MK290403.1 & 1435 (99.65) \\
\hline Bil-LV3_6 & MZ469306 & Paenibacillus sp. MG758020.1 & $1450(99.86)$ \\
\hline Bil-FIN2_3 & MZ469307 & $\begin{array}{l}\text { Bacillus cereus MN068934.1 } \\
\text { B. thuringiensis CP050183.1 }\end{array}$ & $1439(100)$ \\
\hline Bil-FIN-2_5 & MZ469308 & $\begin{array}{c}\text { Staphylococcus warneri CP038242.1 } \\
\text { S. pasteuri MW433878.1 }\end{array}$ & $1437(100)$ \\
\hline Bil-FIN2_6 & MZ469309 & $\begin{array}{c}\text { Staphylococcus warneri CP038242.1 } \\
\text { S. pasteuri MW433878.1 }\end{array}$ & $1437(100)$ \\
\hline Bil-FIN2_7 & MZ469310 & $\begin{array}{c}\text { Lysinibacillus macrolides MH542661.1 } \\
\text { L. xylanilyticus KP644237.1 } \\
\text { L. fusiformis FJ641020.1 }\end{array}$ & $1427(100)$ \\
\hline Bil-FIN2_9 & MZ469311 & Kocuria kristinae KX055834.1 & $1384(100)$ \\
\hline Bil-FIN2_10 & MZ469312 & Weissella hellenica СР042399.1 & $1447(100)$ \\
\hline Bil-FIN2_12 & MZ469313 & Micrococcus terreus KJ781899.1 & $1385(100)$ \\
\hline Bil-FIN2_13 & MZ469314 & Kocuria kristinae KX055834.1 & $1384(100)$ \\
\hline Bil-NOR3_11 & MZ469315 & Staphylococcus sp. KM253075.1 & $1431(100)$ \\
\hline Bil-NOR3_13 & MZ469316 & Corynebacterium freneyi EF462412.1 & $1393(99.86)$ \\
\hline Bil-NOR3_14 & MZ469317 & $\begin{array}{l}\text { Micrococcus sp. KX350143.1 } \\
\text { M. luteus MN826463.1 }\end{array}$ & $1385(100)$ \\
\hline Bil-NOR3_15 & MZ469318 & Pseudomonas monteilii CP013997.1 & $1422(100)$ \\
\hline Bil-NOR3_16 & MZ469319 & Sporosarcina aquimarina MK726086.1 & $1433(100)$ \\
\hline Bil-NOR3_17 & MZ469320 & Paenibacillus xylanexedens CP018620.1 & $1436(99.79)$ \\
\hline Bil-NOR3_18 & MZ469321 & Paenibacillus sp. KR055031.1 & $1427(99.86)$ \\
\hline
\end{tabular}




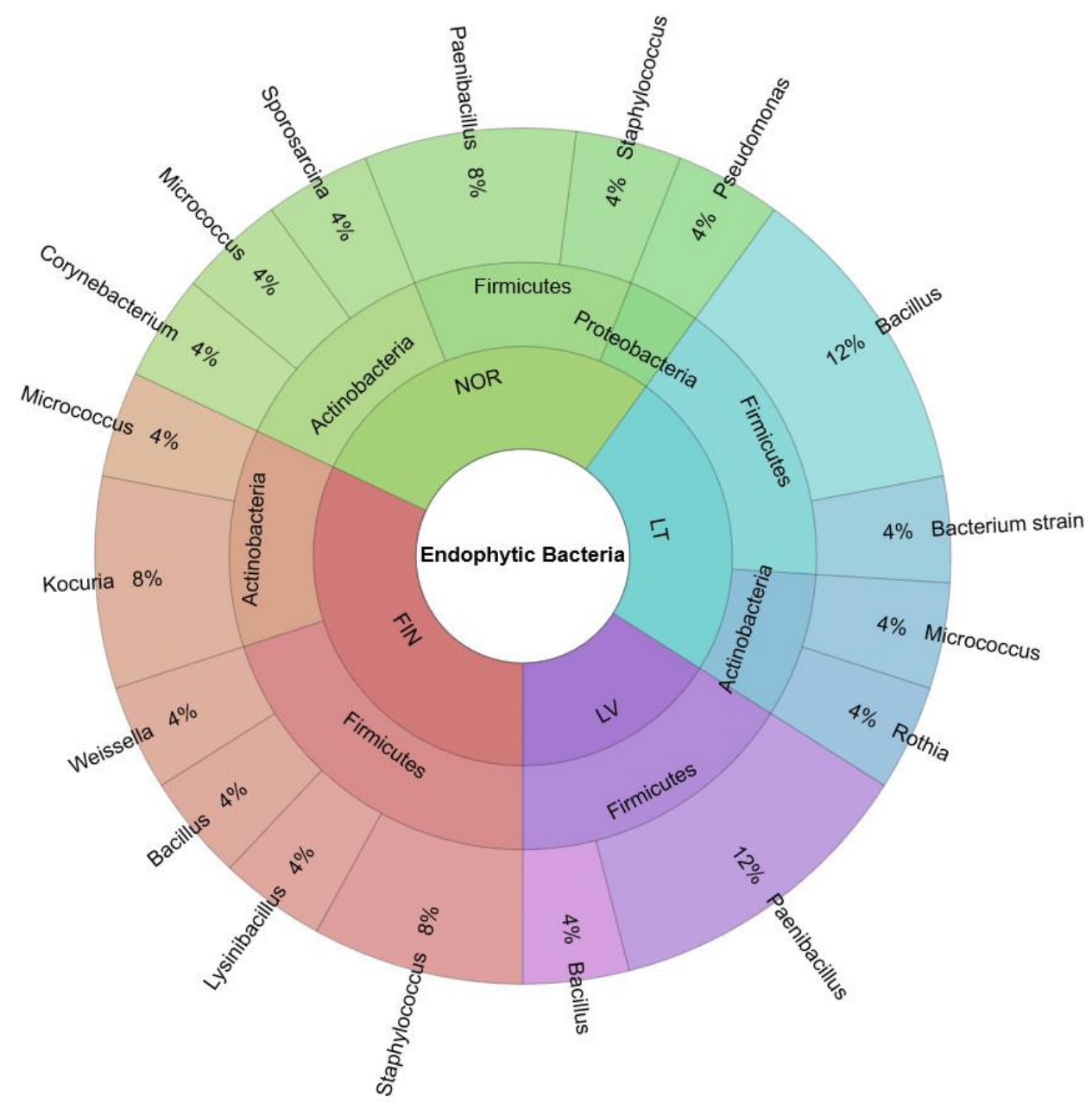

Figure 2. Biodiversity of endophytic bacteria in bilberry leaves of the Baltic-Nordic region's forestsLithuania (LT), Latvia (LV), Finland (FIN) and Norway (NOR).

Endophytic bacteria isolated from Norwegian bilberry leaves belonged to Firmicutes $1 \%$, Actinobacteria $12 \%$, and Proteobacteria $4 \%$ phyla. Meanwhile, bacteria in Finnish and Lithuanian leaf samples belonged to Firmicutes ( $20 \%$ and $16 \%$, respectively) and Actinobacteria $(12 \%$ and $8 \%$, respectively). Only Firmicutes phylum bacteria were isolated from the Latvian samples. Bacteria of the Bacillaceae family were isolated and identified in the bilberry leaves of Lithuania, Latvia, and Finland, but were not found in plant samples from Norway. Bacteria belonging to six different families isolated from leaves samples were collected from the northern countries-Finland and Norway (Figure 2).

\subsection{Enzymatic-Genetic Features of Endophytic Bacteria in Bilberry Leaves}

Enzymatic activity was tested in all bacterial endophytes isolated from bilberry leaves (Table 2). The results showed that amylase was detected in $44 \%$ of the tested isolates, proteases in $56 \%$, and catalases in $88 \%$. The study showed that seven bacterial endophytes isolated from bilberry leaves were able to produce amylase, protease, and catalase. All bacterial endophytes tested had at least one enzymatic activity, except for one bacterial strain, Weissella hellenica Bil-FIN2_10, which lacked amylase, protease, and catalase activity. 
Table 2. Enzymatic activity and the presence of the genes acdS (1-aminocyclopropane-1-carboxylate deaminase (ACCD)) and $A c P h$ (acid phosphatase) in endophytic bacteria isolated from bilberry leaves of the Baltic-Nordic region.

\begin{tabular}{|c|c|c|c|c|c|}
\hline $\begin{array}{l}\text { Endophytic Bacteria Strains } \\
\text { in Different Geographic Locations }\end{array}$ & $\begin{array}{l}\text { Amylolytic } \\
\text { Activity, mm }\end{array}$ & $\begin{array}{l}\text { Proteolytic } \\
\text { Activity, mm }\end{array}$ & $\begin{array}{l}\text { Catalase } \\
\text { Reaction }\end{array}$ & Gene $a c d S$ & Gene AcPho \\
\hline Bacillus sp. Bil-LT1_1 & $11.9 \pm 0.1$ & $10.0 \pm 0.1$ & + & + & - \\
\hline Bacillus sp. Bil-LT1_2 & & & + & - & - \\
\hline Rothia amarae Bil-LT4_1 & $12.0 \pm 0.2$ & $11.8 \pm 0.2$ & + & - & - \\
\hline Bacterium strain Bil-LT4_3 & & $9.8 \pm 0.1$ & + & - & - \\
\hline Bacillus sp. Bil-LT4_7 & $9.0 \pm 0.2$ & $10.2 \pm 01$ & + & - & - \\
\hline Micrococcus sp. Bil-LT4_8 & & $9.3 \pm 0.1$ & + & - & - \\
\hline Bacillus sp. Bil-LV3_1 & $12.5 \pm 0.1$ & $14.2 \pm 0.2$ & + & - & - \\
\hline Paenibacillus tundrae Bil-LV3_3 & $10.1 \pm 0.2$ & $11.9 \pm 0.2$ & + & - & - \\
\hline Paenibacillus sp. Bil-LV3_4 & $12.1 \pm 0.1$ & $10.2 \pm 0.1$ & + & - & - \\
\hline Paenibacillus sp. Bil-LV3_6 & & $10.2 \pm 0.1$ & - & - & - \\
\hline Bacillus sp. Bil-FIN2_3 & $12.3 \pm 0.2$ & $14.3 \pm 0.3$ & - & + & + \\
\hline Staphylococcus sp. Bil-FIN2_5 & & & + & - & - \\
\hline Staphylococcus sp. Bil-FIN2_6 & $11.9 \pm 0.2$ & & + & - & - \\
\hline Lysinibacillus sp. Bil-FIN2_7 & & & + & - & - \\
\hline Kocuria kristinae Bil-FIN2_9 & & & + & + & - \\
\hline Weissella hellenica Bil-FIN2_10 & & & - & - & - \\
\hline Micrococcus terreus Bil-FIN2_12 & & $9.5 \pm 0.1$ & + & - & + \\
\hline Kocuria kristinae Bil-FIN2_13 & & $8.8 \pm 0.1$ & + & - & + \\
\hline Paenibacillus sp. Bil-NOR3_17 & & $10.1 \pm 0.2$ & + & - & - \\
\hline Paenibacillus sp. Bil-NOR3_18 & & & + & - & - \\
\hline Corynebacterium sp. Bil-NOR3_13 & $12.2 \pm 0.1$ & & + & - & - \\
\hline Micrococcus sp. Bil-NOR3_14 & $10.3 \pm 0.2$ & $14.5 \pm 0.2$ & + & - & - \\
\hline Staphylococcus sp. Bil-NOR3_11 & $10.1 \pm 0.1$ & & + & - & - \\
\hline Pseudomonas monteilii Bil-NOR3_15 & & & + & - & - \\
\hline Sporosarcina aquimarina Bil-NOR3_16 & & & + & - & - \\
\hline
\end{tabular}

The results of enzymatic activity (the halo zones on agar in millimeters) are expressed as a mean \pm standard deviation; “+" positive or "_. negative enzymatic reaction and "+" presence or "-_ absence of gene.

Two genes contributing to PGP traits were screened in the endophytic bacterial community. The genes responsible for the synthesis of ACC deaminases (acdS) and / or acid phosphatase (AcPho) were found in five (20\%) isolates of endophytic bacteria (Table 2) belonging to the Mocrococcaceae and Bacillaceae families. Four isolates of endophytic bacteria with genes responsible for overcoming salinity stress and helping absorb insoluble phosphorus from forest soils were found in Finnish leaf samples, and one was found in samples collected in Lithuania. One isolate, Bacillus sp. Bil-FIN2_3, yielded specific PGR fragments of the expected size for both genes. Isolates of Bacillus sp. Bil-LT1_1 and Kocuria kristinae Bil-FIN2_9 produced specific PCR products of the expected size ( $850 \mathrm{bp})$ of the acdS gene. Two bacterial strains from Finland, Micrococcus terreus Bil-FIN2_12 and Kocuria kristinae Bil-FIN2_13, gave an amplified fragment of the expected size ( 734 bp) for the AcPho gene, indicating the potential ability of these isolates to produce acid phosphatase.

\section{Discussion}

V. myrtilus is the most widespread vegetation type in coniferous forests in the BalticNordic region. Although bilberry plants grow in low-pH soil and have a shallow and weak 
root system, deficiency symptoms of nutrition elements $\mathrm{N}$ and $\mathrm{P}$ have not been observed in Norway. Previous research has shown that assimilation of these elements is mainly due to the symbiosis with ericoid mycorrhiza [24]. Given that endophytic bacterial diversity depends on the genotype of the host plant, the bacteria can also have bioactive functions and roles related to the quality of life and survival of the host plant [3,25].

Therefore, studies on endophytic microorganisms of various plants are becoming significant, and this knowledge is being applied in many areas, such as the biomedical field, the food industry, ecological organic agronomy, and others $[7,26,27]$. In this study, we used the bacterial culture method and the $16 \mathrm{~S}$ rRNA gene sequencing technique to analyze the diversity of cultured endophytic bacterial communities isolated from $V$. myrtillus leaves collected from different countries of the North-Baltic region (Figure 1). A collection of 25 different endophytic bacteria was collected (Table 1 and Figure 2). In our study, diversity of the endophytic community was observed, similar to most cultivated plants. Actinobacteria, Firmicutes, and Proteobacteria are the main phyla of endophytic communities in Zea mays L., Medicago sativa L., Piper nigrum L., Vitis spp. L., and Oryza spp. L. plants [9]. Bacillaceae, Peanibacillaceae, Staphylococcaceae, and Micrococcaseae were the major families of endophytic bacterial communities. Bacteria strains belonging to Pseudomonaceae, Lactobacillaceae, and Planococcaceae were found in Norwegian leaves samples and Corynebacteriaceae strains were found in Finnish leaves samples. The novelty of our research is the identification of strain of Microccocus tereus that was not previously found in plants but was present in forest soil [28] and the halophilic bacteria Sporosarcina aquimarina found in our study and previously described only by Janarthine and Eganathan [29] in research on endophytic microorganisms of mangrove Avicennia marina. The strain Lysinibacillus sp. Bil-Fin2_7 should be investigated in the future for its ability to aerobically reduce selenite according to Zhang et al. [19]. Kocuria kristinae was found in bilberry samples from Finland and is not uncommon in cultural plants but is characteristic of the leaves of strawberries grown in the fields [30], as an endophyte of banana shoots [31], switchgrass [32], and grapes [33]. With higher abiotic stress, plants have a greater need for adaptation, and the endophytic community becomes more diverse, leading to increased productivity of plant host metabolites to abiotic and biotic stress [34,35]. In our study, biodiversity of endophytes was greatest in the northern Norway region, and in the warmer regions it decreased.

To better understand the benefits and importance of the endophytic bacterial community for bilberry plants, a study on the production of enzymes and genes associated with plant growth-promoting effects was conducted (Table 2). Some genera of plant endophytic bacteria can produce different types of extracellular enzymes [36-38] and can enhance growth properties and modify metabolism and phytohormone signals in the host plants [39]. In the present study, the isolates tested had good bioactivity properties. In biochemical studies, bacterial endophytes showed extracellular enzymatic activity and amylase, protease, and catalase activity, producing a clear halo zone on LB agar plates. Catalase and protease activities were detected in most bacterial endophytes. Amylase, protease, and catalase activities were confirmed in seven isolates of endophytic bacteria $(28 \%$ of the tested isolates) (Table 2). Vijayalakshmi et al. [40] reported the enzymatic activity of bacterial endophytes in medicinal plants. They found that most of the strains exhibited reasonable enzyme activity for amylase, protease, and cellulase on LB agar plates amended with $1 \%$ substrate. The presence of many enzymatic activities in bacterial strains from samples collected in Lithuania (Bil-LT1_1, Bil-LT4_1, and Bil-LT4_7), Latvia (Bil-LV3_1, BilLV3_3 and Bil-LV3_4), and Norway (Bil-NOR3_14) confirmed that some species of Bacillus, Peanibacillus, and Micrococcus tended to synthesize different enzymes during sporulation. The enzymes amylases and proteases were exhibited by endophytes in bilberry leaves, suggesting a potential role in metabolizing sugar and amino acids. Catalase is mostly found in almost all living organisms that metabolize oxygen. A positive catalase reaction was characteristic of $88 \%$ of bacterial isolates from bilberry leaves. The same results were obtained by Sudewi et al. [41], where positive catalase test results were predominant in endophytic bacteria isolated from rice roots $(89 \%)$. Catalase is useful in a variety of indus- 
trial and medical processes [42], for which bilberry leaf strains can be used. Amylolytic and proteolytic activities were observed in $56 \%$ and $44 \%$ of isolated bacteria from bilberry leaves, respectively, indicating the need for further investigation of these bacteria and their possible use in future use. In this study, the bacterial-specific acdS and AcPho genes were selected for their known benefits to host plants, and for their ability to overcome salinity stress and help absorb insoluble phosphorus from forest soils. The genes acdS and AcPho were established in five bacterial strains. According to PCR studies, three isolates had the ACC gene, including Bacillus sp. Bil-LT1_1, Bacillus sp. Bil-FIN2_3, and Kocuria kristinae Bil-FIN2_9. Microorganisms with the acdS gene were able to produce ACC deaminase, in which the ethylene precursor ACC was converted into $\alpha$-ketobutyrate, indirectly reducing ethylene levels in plants and modulating the plant's resistance to salinity stress [43]. Endophytic bacteria with ACC deaminase activity belong to a wide range of bacterial genera, including Acinetobacter, Achromobacter, Agrobacterium, Alcaligenes, Azospirillum, Bacillus, Burkholderia, Enterobacter, Pseudomonas, Ralstonia, Serratia, and Rhizobium bacteria [44,45]. Thus, only three strains of bilberry leaves could produce ACC deaminase. Phosphate solubilization was mostly observed in endophytic bacteria. For example, approximately $59-100 \%$ of endophytic populations from cactus, strawberry, sunflower, soybean, and other legumes were mineral phosphate solubilizers [3]. In our study, the AcPho gene was found in Bacillus sp. Bil-FIN2_3, Micrococcus terreus Bil-FIN2_12, and Kocuria kristinae Bil-FIN2_13, and, according to other studies, these strains could dephosphorylate various organic phosphodiesters [46] and play an important role in mineralizing plant organic phosphorous [47]. It is likely that $V$. myrtillus plants from acidic soils in Lithuania and Latvia also need endophytes to help them adapt and to carry out phosphorus metabolism.

\section{Conclusions}

A community of 25 microorganisms was found in the leaves of bilberry (Vaccinium myrtillus L.). The study showed that isolates with proteolytic and amylases activity indicated the possible expression of these enzymes and their potential role in the degradation of starch and protein organic matter in the ecosystem. Ninety-six percent of endophytic bacteria strains of $V$. myrtillus L. had positive enzymatic activity and $20 \%$ had functional plant growth-promoting traits. The accumulation of this new collection of microorganisms and the primary genetic-enzymatic analysis opens opportunities for the study of some isolates against pathogenic organisms and for reducing the effects of salinity stress on other plants.

Author Contributions: Original idea and conceptualization A.Š. All the authors have participated in the research investigation, data analysis, original draft preparation, review and editing. All authors have read and agreed to the published version of the manuscript.

Funding: European Regional Development Fund through Interreg Baltic Sea Region Program; European Regional Development Fund through Interreg Nord.

Informed Consent Statement: Not applicable.

Data Availability Statement: The sequencing data of this study are publicly available through the NCBI GenBank (https: / /www.ncbi.nlm.nih.gov/, accessed on 31 August 2021).

Conflicts of Interest: The authors declare no competing interest.

\section{References}

1. Santoyo, G.; Moreno-Hagelsieb, G.; del Carmen Orozco-Mosqueda, M.; Glick, B.R. Plant growth-promoting bacterial endophytes. Microbiol. Res. 2016, 183, 92-99. [CrossRef] [PubMed]

2. Qin, S.; Xing, K.; Jiang, J.H.; Xu, L.H.; Li, W.J. Biodiversity, bioactive natural products and biotechnological potential of plant-associated endophytic actinobacteria. Adv. Appl. Microbiol. 2011, 89, 457-473. [CrossRef]

3. Afzal, I.; Shinwaria, Z.K.; Sikandarb, S.; Shahzadc, S. Plant beneficial endophytic bacteria: Mechanisms, diversity, host range and genetic determinants. Microbiol. Res. 2019, 221, 36-49. [CrossRef] [PubMed]

4. Coombs, J.T.; Franco, C.M.M. Isolation and identification of actinobacteria from surface-sterilized wheat roots. Appl. Environ. Microbiol. 2003, 69, 5603-5608. [CrossRef] [PubMed] 
5. Glick, B.R. Bacteria with ACC deaminase can promote plant growth and help to feed the world. Microbiol. Res. 2014, 169, 30-39. [CrossRef]

6. Mora, Y.; Díaz, R.; Vargas-Lagunas, C.; Peratta, H.; Guerrero, G.; Aguilar, A.; Encarnación, S.; Girard, L.; Mora, L. Nitrogen-fixing rhizobial strains isolated from common bean seeds: Phylogeny, physiology, and genome analysis. Appl. Environ. Microbiol. 2014, 80, 5644-5654. [CrossRef] [PubMed]

7. Gouda, S.; Das, G.; Sen, S.K.; Shin, H.S.; Patra, J.K. Endophytes: A Treasure House of Bioactive Compounds of Medicinal Importance. Front. Microbiol. 2016, 7, 1538. [CrossRef] [PubMed]

8. Rosenblueth, M.; Martínez-Romero, E. Bacterial endophytes and their interactions with hosts. Mol. Plant Microbe Interact. 2006, 19, 827-837. [CrossRef] [PubMed]

9. Miliute, I.; Buzaite, O.; Baniulis, D.; Stanys, V. Bacterial endophytes in agricultural crops and their role in stress tolerance: A review. Zemdirbyste 2015, 102, 465-478. Available online: https:/ / hdl.handle.net/20.500.12259/52375 (accessed on 26 November 2021). [CrossRef]

10. Anyasi, R.O.; Atagana, H.I. Endophyte: Understanding the microbes and its applications. Pak. J. Biol. Sci. 2019, 22, 154-167. Available online: https:/ / scialert.net/abstract/?doi=pjbs.2019.154.167 (accessed on 26 November 2021). [CrossRef] [PubMed]

11. Xu, W.; Wang, F.; Zhang, M.; Ou, T.; Wang, R.; Strobel, G.; Xiang, Z.; Zhou, Z.; Xie, J. Diversity of cultivable endophytic bacteria in mulberry and their potential for antimicrobial and plant growth-promoting activities. Microbiol. Res. 2019, 229, 126328. [CrossRef]

12. Senthilkumar, M.; Anandham, R.; Madhaiyan, M.; Venkateswaran, V.; Sa, T. Endophytic 895 bacteria: Perspectives and applications in agricultural crop production. In Bacteria in Agrobiology: Crop 896 Ecosystems; Springer: Berlin/Heidelberg, Germany, 2011; pp. 61-96.

13. Dastogeer, K.M.G.; Tumpa, F.H.; Sultana, A.; Akter, M.A.; Chakraborty, A. Plant microbiome-an account of the factors that shape community composition and diversity. Curr. Plant Biol. 2020, 23, 100161. [CrossRef]

14. Bujor, O.; Le, B.C.; Volf, I.; Popa, V.I.; Dufour, C. Seasonal variations of the phenolic constituents in bilberry (Vaccinium myrtillus L.) leaves, stems and fruits, and their antioxidant activity. Food Chem. 2016, 213, 58-68. [CrossRef] [PubMed]

15. Ziemlewska, A.; Zagórska-Dziok, M.; Nizioł-Łukaszewska, Z. Assessment of cytotoxicity and antioxidant properties of berry leaves as by-products with potential application in cosmetic and pharmaceutical products. Sci. Rep. 2021, 11, 3240. [CrossRef] [PubMed]

16. Hardoim, P.R.; van Overbeek, L.S.; Elsas, J.D. Properties of bacterial endophytes and their proposed role in plant growth. Trends Microbiol. 2008, 16, 463-471. [CrossRef] [PubMed]

17. Hardoim, P.R.; van Overbeek, L.S.; Berg, G.; Pirttilä, A.M.; Company, S.; Campisano, A.; Döring, M.; Sessitsch, A. The Hidden World within Plants: Ecological and Evolutionary Considerations for Defining Functioning of Microbial Endophytes. Microbiol. Mol. Biol. Rev. 2015, 79, 293-320. [CrossRef] [PubMed]

18. Singh, M.; Kumar, A.; Singh, R.; Pandey, K.D. Endophytic bacteria: A new source of bioactive compounds. 3 Biotech. 2017, 7, 315. [CrossRef]

19. Zhang, J.; Wang, Y.; Shao, Z.; Li, J.; Zan, S.; Zhou, S.; Yang, R. Two selenium tolerant Lysinibacillus sp. strains are capable of reducing selenite to elemental Se efficiently under aerobic conditions. J. Environ. Sci. 2019, 77, 238-249. [CrossRef] [PubMed]

20. Baker, G.C.; Smith, J.J.; Cowan, D.A. Review and re-analysis of domain-specific 16 S primers. J. Microbiol. Methods 2003, 55, 541-555. [CrossRef] [PubMed]

21. Ondov, B.D.; Bergman, N.H.; Phillippy, A.M. Interactive metagenomic visualization in a Web browser. BMC Bioinform. 2011, 12, 385. [CrossRef]

22. Fouda, A.; Eid, A.M.; Elsaied, A.; El-Belely, E.F.; Barghoth, M.G.; Azab, E.; Gobouri, A.A.; Hassan, S.E. Plant Growth-Promoting Endophytic Bacterial Community Inhabiting the Leaves of Pulicaria incisa (Lam.) DC Inherent to Arid Regions. Plants 2021, 10, 76 [CrossRef]

23. Lyngwi, N.A.; Nongkhlaw, M.; Kalita, D.; Joshi, S.R. Bioprospecting of Plant Growth Promoting Bacilli and Related Genera Prevalent in Soils of Pristine Sacred Groves: Biochemical and Molecular Approach. PLoS ONE 2016, 11, e0152951. [CrossRef] [PubMed]

24. Myers, M.D.; Leake, J.R. Phosphodiesters as mycorrhizal P sources. II. Ericoid mycorrhiza and the utilization of nuclei as a phosphorus and nitrogen source by Vaccinium macrocarpon. New Phytologist. 1996, 132, 445-451. [CrossRef]

25. Papik, J.; Folkmanova, M.; Polivkova-Majorova, M.; Suman, J.; Uhlik, O. The invisible life inside plants: Deciphering the riddles of endophytic bacterial diversity. Biotechnol. Adv. 2020, 44, 107614. [CrossRef]

26. Radha, S.; Ashok, D.K. Diversity and Applications of Endophytic Actinobacteria of Plants in Special and Other Ecological Niches. Front. Microbiol. 2018, 9, 1767. [CrossRef]

27. Ek-Ramos, M.J.; Gomez-Flores, R.; Orozco-Flores, A.A.; Rodríguez-Padilla, C.; González-Ochoa, G.; Tamez-Guerra, P. Bioactive Products From Plant-Endophytic Gram-Positive Bacteria. Front. Microbiol. 2019, 10, 463. [CrossRef] [PubMed]

28. Zhang, J.-Y.; Liu, X.-Y.; Liu, S.-J. Agrococcus terreus sp. nov. and Micrococcus terreus sp. nov., isolated from forest soil. Int. J. Syst. Evol. Microbiol. 2010, 60, 1897-1903. [CrossRef] [PubMed]

29. Janarthine, S.R.S.; Eganathan, P. Plant Growth Promoting of Endophytic Sporosarcina aquimarina SjAM16103 Isolated from the Pneumatophores of Avicennia marina L. Int. J. Microbiol. 2012, 2012, 532060. [CrossRef] [PubMed]

30. Kukkurainen, S.; Leino, A.; Vähämiko, S.; Kärkkäinen, H.R.; Ahanen, K.; Sorvari, S.; Rugienius, R.; Toldi, O. Occurrence and Location of Endophytic Bacteria in Garden and Wild Strawberry. HortScience 2005, 40, 348-352. [CrossRef] 
31. Thomas, P.; Soly, T.A. Endophytic Bacteria Associated with Growing Shoot Tips of Banana (Musa sp.) cv. Grand Naine and the Affinity of Endophytes to the Host. Microb. Ecol. 2009, 58, 952-964. Available online: http://www.jstor.org/stable/27770582 (accessed on 26 November 2021). [CrossRef] [PubMed]

32. Xia, Y.; Greissworth, E.; Mucci, C.; Williams, M.A.; Debolt, S. Characterization of culturable bacterial endophytes of switchgrass (Panicum virgatum L.) and their capacity to influence plant growth. Glob. Change Biol. Bioenergy 2013, 5, 674-682. [CrossRef]

33. Pacifico, D.; Squartini, A.; Crucitti, D.; Barizza, E.; Lo Schiavo, F.; Muresu, R.; Carimi, F.; Zottini, M. The Role of the Endophytic Microbiome in the Grapevine Response to Environmental Triggers. Front. Plant Sci. 2019, 10, 1256. [CrossRef] [PubMed]

34. Wani, Z.A.; Ashraf, N.; Mohiuddin, T.; Riyaz-Ul-Hassan, S. Plant-endophyte symbiosis, an eco-logical perspective. Appl. Microbiol. Biotechnol. 2015, 99, 2955-2965. [CrossRef]

35. Miliute, I.; Buzaite, O.; Gelvonauskiene, D.; Sasnauskas, A.; Stanys, V.; Baniulis, D. Plant growth promoting and antagonistic properties of endophytic bacteria isolated from domestic apple. Zemdirbyste 2016, 103, 77-82. [CrossRef]

36. Ponnuraj, K.; Nessi, C.; Setlow, P.; Jedrzejas, M.J. Structural studies of a novel germination protease from spores of Bacillus megaterium. J. Struct. Biol. 1999, 125, 19-24. [CrossRef] [PubMed]

37. Kamasaka, H.; Sagimoto, K.; Takata, H.; Nishimura, T.; Kuirk, T. Bacillus stearothermophilus Neopullulase selective hydrolysis of amulose to maltose in the presence of amylopectin. Appl. Environ. Microbiol. 2002, 6, 1658-1664. [CrossRef] [PubMed]

38. Traving, S.J.; Thygesen, U.H.; Riemann, L.; Stedmon, C.A. A model of extracellular enzymes in free-living microbes: Which strategy pays off? Appl. Environ. Microbiol. 2015, 81, 7385-7393. [CrossRef]

39. Sturz, A.V.; Christie, B.R.; Nowak, J. Bacterial endophytes: Potential role in developing sustain-able systems of crop production. CRC Crit Rev Plant Sci 2000, 19, 1-30. [CrossRef]

40. Vijayalakshmi, R.; Kairunnisa1, K.; Sivvaswamy, N.S.; Dharan, S.S.; Natarajan, S. Enzyme production and antimicrobial activity of endophytic bacteria isolated from medicinal plants. Indian J. Technol. 2016, 9, 1-8. [CrossRef]

41. Sudewi, S.; Ala, A.; Baharuddin, F.M. The isolation, characterization endophytic bacteria from roots of local rice plant Kamba in, Central Sulawesi, Indonesia. Biodiversitas 2020, 21, 1614-1624. [CrossRef]

42. Babiker, B.M.; Ahmed, M.A.E.; Ibrahim, H.M. Isolation \& identification of catalase producing Bacillus spp.: A comparative study. Int. J. Adv. Res. 2016, 4, 1206-1211. Available online: https://www.journalijar.com/uploads/493_IJAR-8701.pdf (accessed on 26 November 2021).

43. Bouffaud, M.L.; Renoud, S.; Dubost, A.; Moënne-Loccoz, Y.; Muller, D. Aminocyclopropane-1-carboxylate deaminase producers associated to maize and other Poaceae species. Microbiome 2018, 6, 114. [CrossRef] [PubMed]

44. Zahir, Z.A.; Ghani, U.; Naveed, M.; Nadeem, S.M.; Asghar, H.N. Comparative effectiveness of Pseudomonas and Serratia sp. containing ACC-deaminase for improving growth and yield of wheat (Triticum aestivum L.) under salt-stressed conditions. Arch. Microbiol. 2009, 191, 415-424. [CrossRef] [PubMed]

45. Kang, B.G.; Kim, W.T.; Yun, H.S.; Chang, S.C. Use of plant growth-promoting rhizobacteria to control stress responses of plant roots. Plant Biotechnol. Rep. 2010, 4, 179-183. [CrossRef]

46. Neal, A.L.; Blackwell, M.; Akkari, E.; Guyomar, S.; Clark, I.; Hirsch, P.R. Phylogenetic distribution, biogeography and the effects of land management upon bacterial non-specific Acid phosphatase Gene diversity and abundance. Plant Soil 2018, 427, 175-189. [CrossRef] [PubMed]

47. Rodriguez, H.; Fraga, R. Phosphate solubilizing bacteria and their role in plant growth promotion. Biotechnol. Adv. 1999, 17, 319-339. [CrossRef] 